\title{
PENERAPAN SISTEM INFORMASI MANAJEMEN DAERAH (SIMDA) BARANG MILIK DAERAH PADA BADAN PENGELOLA KEUANGAN DAN ASET DAERAH KOTA MANADO
}

\author{
Sepang Gisella Monica ${ }^{1}$, David P.E Saerang ${ }^{2}$, Sonny Pangerapan ${ }^{3}$ \\ ${ }^{123}$ Fakultas Ekonomi dan Bisnis, Jurusan Akuntansi, Universitas Sam Ratulangi, Jl.Kampus Bahu, Manado \\ 95115, Indonesia \\ E-mail: gisellasepang@yahoo.com
}

\begin{abstract}
Regional management information system application is a computer application program that is integrated and can help the process of the administration of the local government from the provincial level, city level until the sub-district level. SIMDA consists of 26 separate application that can be distributed to construct the SKPD with ntegrated database system so that the output can be used by the regional government to help the decision making process. The purpose of this research is to know the Applying of Regional Management Information System Regional Assets on Financial and Asset Management Agency of the city of Manado. The analysis method used is qualitative descriptive method. The results of the study showed that the applying of the SIMDA-BMD on BPKAD had run well, starting from planning, procurement, use, administration, utilization, maintanence and deletion are well under way, but there is a weakness in this application which cannot be used on windows 10.
\end{abstract}

Keywords: Regional Management Information System, Regional Assets.

\section{PENDAHULUAN \\ 1.1 Latar Belakang}

Instansi Pemerintah adalah penyelenggara pemerintahan, dan sebagai pengguna anggaran negara wajib untuk melakukan pengelolaan keuangan dalam mempertanggungjawabkan tugas pokok dan fungsinya berdasarkan suatu perencanaan yang ditetapkan oleh masing-masing instansi. Penerapan sistem pertanggungjawaban tersebut harus tepat, jelas, terukur dan legitimate sehingga penyelenggaraan pemerintah dapat berlangsung bersih dan bertanggungjawab.

Antara pengelolaan dan pertanggungjawaban atas barang milik negara dengan pengelolaan dan pertanggungjawaban keuangan negara memiliki hubungan yang sangat jelas. Pengelolaan dan pertanggungjawaban atas barang milik negara menjadi kesatuan dan tidak dapat dipisahkan dalam pengelolaan dan pertanggungjawaban keuangan negara. Bentuk pertanggungjawaban atas pengelolaan keuangan dimana BMN termasuk di dalamnya adalah bentuk laporan keuangan pemerintah pusat.

Mengingat pentingnya peranan laporan keuangan dalam menyajikan informasi pelaksanaan APBN/APBD yang mempengaruhi kebijakan fiskal dan moneter untuk menggerakkan perekonomian nasional yang sehat, Menteri Keuangan selaku pemegang kekuasaan fiskal menunjuk Direktorat Jenderal Perbendaharaan (DJPB) sebagai pembuat dan pembina Sistem Akuntansi Pemerintah (SiAP). Wujud pelaksanaan tugas sebagai pembuat dan pembina sistem oleh DJPB adalah lahirnya berbagai peraturan dan aplikasi komputer yang digunakan oleh seluruh instansi pemerintah di semua level, mulai tingkat Kementerian sampai dengan Satuan Kerja (Satker) (Nasrun dkk., 2012).. Oleh karena itu, dalam pengelolaan dan pertanggungjawaban atas barang milik daerah telah dibuatkan sebuah sistem yang diberi nama Sistem Informasi Manajemen Daerah Barang Milik Daerah atau disebut SIMDA-BMD, sedangkan dalam pengelolaan dan pertanggungjawaban keuangan negara 
terdapat sebuah sistem yang diberi nama Sistem Akuntansi Keuangan (SAK) kedua sistem tersebut tergabung dalam suatu sistem yakni Sistem Akuntansi Instansi (SAI). Sistem Informasi Manajemen Daerah Barang Milik Negara (SIMDA-BMN) diselenggarakan dengan tujuan untuk menghasilkan informasi yang diperlukan sebagai alat pertanggungjawaban atas pelaksanaan APBN/APBD serta pengelolaan/pengendalian BMD yang dikuasai oleh suatu unit akuntansi pengguna barang (Pamungkas dkk., 2011).

Dalam penatausahaan aset daerah, pengurus barang merupakan personil yang bertugas mengoperasikan aplikasi SIMDA-BMD. Dalam melakukan pemrosesan data BMD, pengurus barang dapat memanfaatkan 7 menu Data Entry di aplikasi SIMDA-BMD Yaitu Perencanaan, Pengadaan, Penggunaan, Penatausahaan, Pemanfaatan, Pemeliharaan, Penghapusan

Badan Pengelola Keuangan dan Aset Daerah Kota Manado sebagai suatu organisasi yang menggunakan pembiayaan APBD harus mampu mengelola keuangan daerah secara efektif dan efisien sebagai wujud pertanggungjawaban publiknya. Untuk mencapai hal tersebut, maka Badan Pengelola Keuangan dan Aset Daerah Kota Manado telah menerapkan sistem informasi manajemen daerah terhadap barang milik daerah, oleh karena itu penulis tertarik melakukan peninjauan dan penelitian dengan judul Penerapan Sistem Informasi Manajemen Daerah Barang Milik Daerah pada Badan Pengelola Keuangan dan Aset Daerah Kota Manado.

\section{TINJAUAN PUSTAKA}

\subsection{Konsep Akuntansi}

Halim dan Kusufi (2012: 36), mendefinisikan akuntansi sebagai suatu proses pengidentifikasian, pengukuran, pencatatan, dan pelaporan transaksi ekonomi (keuangan) dari suatu organisasi/entitas yang dijadikan sebagai informasi dalam rangka pengambilan keputusan ekonomi oleh pihak-pihak yang memerlukan. Suwardjono (2013: 10), menyatakan bahwa akuntansi sebagai kegiatan penyediaan jasa mengisyaratkan bahwa akuntansi yang akhirnya harus diterapkan untuk merancang dan menyediakan jasa berupa informasi keuangan harus bermanfaat untuk kepentingan sosial dan ekonomik negara tempat akuntansi diterapkan. Dapat disimpulkan Akuntansi adalah sebuah sistem informasi yang mengukur aktivitas bisnis pemrosesan data menjadi laporan dan mengkomunikasikan hasilnya pada para pengambil keputusan.

Menurut Winston Pontoh (2013: 2) akuntansi pada dasarnya akan menghasilkan informasi dari sebuah sistem akuntansi yang ada di dalam sebuah entitas atau organisasi bisnis yang disebut dengan informasi akuntansi yang akan dimanfaatkan oleh pengguna seperti masyarakat umum, masyarakat intelektual (termasuk didalamnya mahasiswa atau peneliti) dan para pengambil keputusan bisnis dalam organisasi.

\subsection{Konsep Akuntansi Sektor Publik}

Mardiasmo (2012: 37) dalam pengertian umum yang khususnya bagi dunia akuntansi di negara-negara maju organisasi sektor publik terbagi dalam tiga kelompok besar yaitu ;

1. Pemerintah pusat, yang terdiri dari kementerian dan badan-badan di bawah pemerintah eksekutif;

2. Pemerintah daerah, bagi tingkat provinsi maupun kabupaten/kota;

3. Industri atau perusahaan untuk kepentingan publik atau masyarakat luas.

Standar Akuntansi Pemerintahan (SAP) diterapkan di lingkup pemerintahan, yaitu pemerintah pusat, pemerintah daerah dan satuan organisasi di lingkungan pemerintah pusat/daerah jika menurut peraturan perundang-undangan satuan organisasi dimaksud wajib menyajikan laporan keuangan. Akuntansi Sektor publik, lingkupnya cukup kompleks meliputi multi entitas ekonomi dan legal yang beraneka ragam dengan latar belakangnya. Pengembangan pemahaman karakter sektor publik perlu dilakukan dengan pertimbangan : 
a. Perubahan persepsi masyarakat terhadap kinerja pemerintahan di bidang pelayanan;

b. Untuk memperbaiki kinerja pemerintah, maka kelembagaan negara, pemerintah, entitas ekonomi, dan satuan satuan kerja sektor publik, dilakukan berdasar prinsip transparansi, partisipasi, akuntabilitas dan standar mutu pelayanan yang prima (excellence service).

\subsection{Akuntansi Pemerintahan}

Dalam akuntansi pemerintahan, data akuntansi digunakan untuk memberikan informasi mengenai transaksi ekonomi dan keuangan pemerintah kepada pihak eksekutif, legislatif, dan masyarakat. Halim (2013: 1) menyatakan bahwa akuntansi pemerintahan daerah di Indonesia merupakan salah satu bidang dalam akuntansi sektor publik yang mendapat perhatian besar dari berbagai pihak semenjak reformasi tahun 1998. Sujarweni (2015: 18) mendefinisikan akuntansi pemerintahan adalah akuntansi yang bersangkutan dengan bidang keuangan negara, dari anggaran sampai dengan pelaksanaan dan pelaporannya, termasuk segala pengaruh yang ditimbulkannya.

Sadeli (2015: 6) menyatakan akuntansi pemerintahan termasuk pula akuntansi lembaga-lembaga nonprofit atau institusional accounting, mengkhususkan pada masalah pencatatan dan pelaporan transaksi dari unit-unit pemerintah dan organisasi nonprofit lainnya, seperti: mesjid, lembaga amal, yayasan, rumah sakit, dan lembaga-lembaga pendidikan.

\subsection{Standar Akuntansi Pemerintahan}

Standar Akuntansi Pemerintahan (SAP) ditetapkan dengan Peraturan Pemerintah No. 71 Tahun 2010 sebagai pengganti Peraturan Pemerintah No. 24 Tahun 2005. SAP dinyatakan dalam bentuk Pernyataan Standar Akuntansi Pemerintahan (PSAP), dilengkapi dengan Pengantar Standar Akuntansi Pemerintahan dan disusun mengacu kepada Kerangka Konseptual Akuntansi Pemerintahan.

Manfaat standar akuntansi pemerintahan adalah sebagai berikut:

1. Standar akuntansi digunakan oleh akuntan keuangan di pemerintahan sebagai pedoman dalam penyusunan dan penyajian laporan keuangan pemerintahan;

2. Standar akuntansi digunakan oleh auditor sebagai kriteria audit untuk menentukan apakah laporan keuangan yang disajikan sudah sesuai dengan standar akuntansi yang mengaturnya;

3. Standar akuntansi digunakan oleh pengguna laporan keuangan untuk memahami laporan keuangan dan menghindari kesalahan dalam menginterpretasikan informasi dalam laporan keuangan;

4. Standar akuntansi diperlukan untuk meningkatkan kualitas laporan keuangan yaitu meningkatkan konsistensi, daya banding, keterpahaman, relevansi, dan keandalan laporan keuangan; dan

5. Standar akuntansi menjadi acuan dalam penyusunan sistem akuntansi sebab keluaran sistem akuntansi harus sesuai dengan standar akuntansi.

\subsubsection{Ruang Lingkup Standar Akuntansi Pemerintahan}

SAP diterapkan di lingkup pemerintahan, yaitu pemerintahan pusat dan pemerintahan daerah, menurut peraturan perundang-undangan satuan organisasi dimaksud wajib menyajikan laporan keuangan. Ruang lingkup SAP mengacu pada kerangka konseptual akuntansi pemerintahan menurut Peraturan Pemerintah Nomor 71 Tahun 2010 tentang Standar Akuntansi Pemerintahan (SAP) adalah:

1. Lingkungan akuntansi pemerintahan;

2. Pengguna dan kebutuhan informasi para pengguna;

3. Entitas akuntansi dan entitas pelaporan;

4. Peranan dan tujuan pelaporan keuangan, komponen laporan keuangan, serta dasar hukum; 
5. Asumsi dasar, karakteristik kualitatif yang menentukan manfaat informasi dalam laporan keuangan, prinsip-prinsip, serta kendala informasi akuntansi;

6. Unsur-unsur yang membentuk laporan keuangan, pengakuan, dan pengukurannya.

\subsubsection{Tujuan dan Peranan Standar Akuntansi Pemerintahan}

Tujuan diterapkannya standar akuntansi pemerintahan adalah untuk mewujudkan transparansi dan akuntabilitas pengelolaan keuangan pemerintah baik pusat maupun daerah. Secara rinci Standar Akuntansi Pemerintahan bertujuan untuk:

1. Akuntabilitas, mempertanggungjawabkan pengelolaan dan pelaksanaan kebijakan sumber daya dalam mencapai tujuan;

2. Manajemen, memudahkan fungsi perencanaan, pengelolaan dan pengendalianatas aset, kewajiban dan ekuitas dana pemerintah;

3. Transparansi, memberikan informasi keuangan yang terbuka, jujur, menyeluruh kepada stakeholders;

4. Keseimbangan Antargenerasi, memberikan informasi mengenai kecukupan penerimaan pemerintah untuk membiayai seluruh pengeluaran, dan apakah generasi yang akan datang ikut menanggung beban pengeluaran tersebut.

\subsection{Sistem Informasi Manajemen Daerah (SIMDA)}

Aplikasi sistem informasi manajemen daerah merupakan program aplikasi komputer yang terintegrasi dan dapat membantu proses administrasi pemerintah daerah dari tingkat provinsi, kabupaten/kota, sampai tingkat kecamatan dan kelurahan. SIMDA terdiri dari 26 aplikasi terpisah yang dapat didistribusikan di setiap SKPD dengan sistem database terintegrasi, sehingga outputnya dapat dipergunakan oleh pimpinan daerah untuk membantu proses pengambilan keputusan. Di sisi lain pihak legislatif dapat menggunakannya untuk melakukan monitoring terhadap kinerja pemerintah daerah. SIMDA merupakan salah satu upaya dalam rangka memenuhi kebutuhan informasi secara cepat, tepat, lengkap, akurat, dan terpadu, untukmenunjang proses administrasi pemerintahan, pelayanan masyarakat, dan memfasilitasi partisipasi dan dialog publik dalam perumusan kebijakan.

Dalam penatausahaan aset daerah, pengurus barang merupakan personil yang bertugas mengoperasikan aplikasi SIMDA-BMD. Dalam melakukan pemrosesan data BMD, pengurus barang dapat memanfaatkan 7 menu Data Entry di aplikasi SIMDA-BMD yaitu :

\section{Perencanaan}

Prosedur perencanaan merupakan tahap awal dalam siklus pengelolaan BMD. Di dalam aplikasi SIMDA-BMD prosedur perencanaan mencakup Rencana

Pengadaan dan Rencana Pemeliharaan. Perencanaan adalah rangkaian kegiatan dalam memenuhi kebutuhan dengan memperhatikan kemampuan keuangan daerah, dan secara terinci memuat nama barang, banyaknya barang, waktu dan biaya.

Perencanaan dan Penganggaran disusun dalam Rencana Anggaran SKPD,

perencanaan dan penganggaran di BPKAD disusun berdasarkan standarisasi BMD, standarisasi kebutuhan BMD dan standarisasi harga yang dibutuhkan. Proses perencanaan untuk kebutuhan barang dalam BPKAD dilaksanakan sebagai berikut: Kuasa Pengguna mengajukan usul rencana kebutuhan barang (RKBMD) kepada Pengguna untuk disampaikan kepada Pengelola Barang dengan melihat barang-barang apa saja yang dibutuhkan. Usulan tersebut ditetapkan sebagai Rencana Kebutuhan BMD (RKBMD) setelah dibahas oleh Pengelola bersama Pengguna dengan memperhatikan hasil inventarisasi barang yang dikuasai pengguna barang. 


\section{Pengadaan}

Prosedur pengadaan pada aplikasi SIMDA-BMD merupakan prosedur lanjutan dari prosedur perencanaan yang mencakup Data Pengadaan (untuk aset baru) dan Inventarisasi/sensus (untuk aset yang sudah ada). Pada bagian Data Pengadaan dapat digunakan untuk memantau proses pengadaan BMD sebelum dicatat sebagai aset. Dalam prosedur ini meliputi pencatatan data kontrak/Surat Perintah Kerja, Surat Perintah Pencairan Dana (SP2D) Termin dan SP2D Penunjang dan diakhiri dengan posting ke KIB.

Sedangkan pada bagian Inventarisasi dapat dimanfaatkan untuk melakukan

penambahan aset dari hasil inventarisasi/sensus BMD yang mencakup Tanah (KIB A); Peralatan dan Mesin (KIB B); Gedung dan Bangunan (KIB C); Jalan, Jaringan dan Irigasi (KIB D); Buku dan Perpustakaan, Barang Bercorak Kebudayaan serta Hewan, Ternak dan Tumbuhan (KIB E); dan Konstruksi Dalam Pengerjaan (KIB F).

\section{Penggunaan}

Prosedur penggunaan dapat dimanfaatkan untuk mencatat data pengguna/pemakai BMD berdasarkan Surat Keputusan Penggunaan BMD yang telah ditetapkan. Penetapan status penggunaan barang milik daerah berupa tanah dan bangunan dilakukan apabila diperlukan untuk kepentingan penyelenggaraan tugas dan fungsi pengguna barang atau kuasa pengguna barang yang bersangkutan.

Penetapan status penggunaan BMD oleh Kepala Daerah yaitu dimulai dari pengguna barang mengajukan permohonan penetapan status penggunaan barang milik daerah yang diperoleh dari beban APBD dan perolehan lainnya yang sah kepada Gubernur/Bupati/Walikota. Pengajuan permohonan penetapan status penggunaan barang milik daerah oleh Kepala Daerah dilakukan setelah diterimanya barang milik daerah berdasarkan dokumen penerimaan barang pada tahun anggaran yang berkenaan. Kepala Daerah (Gubernur/Bupati/Walikota) menerbitkan keputusan penetapan status penggunaan barang milik daerah setiap tahun.

\section{Penatausahaan}

Pengguna/Kuasa pengguna wajib mencatat BMD pada Daftar Barang Pengguna (DBP)/(DBKP) yang disediakan secara teratur dan menyimpan bukti kepemilikkannya. Prosedur penatausahaan dalam BPKAD merupakan prosedur yang digunakan untuk mengelola BMD dalam kegiatan mengubah data, memindah/mutasi BMD, kapitalisasi, koreksi dan mengubah kondisi BMD.

Hasil dari penatausahaan BMD di BPKAD digunakan untuk penyusunan neraca pemerintah daerah, perencanaan kebutuhan pengadaan dan pemeliharaan BMD setiap tahun untuk digunakan sebagai bahan penyusunan rencana anggaran dan untuk pengamanan administratif terhadap barang milik daerah.

\section{Pemanfaatan}

Prosedur pemanfaatan digunakan untuk mengelompokan BMD berdasarkan pemanfaatannya. Dalam aplikasi SIMDA-BMD jenis-jenis pemanfaatan meliputi: fasilitas sosial, fasilitas umum, sewa guna usaha, kerja sama operasi, bangun serah guna dan bangun guna serah. Pemanfaatan barang milik daerah dapat dilakukan sepanjang tidak mengganggu pelaksanaan tugas dan fungsi penyelenggaraan pemerintahan daerah.

Barang milik daerah yang menjadi objek pemanfaatan harus ditetapkan status penggunaannya oleh pengelola barang/pengguna barang, dan barang milik daerah yang menjadi objek pemanfaatan dilarang dijaminkan atau digadaikan. 
6. Pemeliharaan

Prosedur ini dimaksudkan untuk mengolah data transaksi pemeliharaan BMD yang akan tercatat dalam riwayat namun tidak menambah kapitalisasi aset.

Rencana Kebutuhan Barang Milik Daerah (RKBMD) pemeliharaan barang milik daerah tidak dapat diusulkan oleh pengguna barang dan/atau kuasa pengguna barang terhadap barang milik daerah yang berada dalam kondisi rusak berat, barang milik daerah yang sedang dalam status penggunaan sementara. RKBMD pemeliharaan BMD diusulkan oleh pengguna barang yang sementara menggunakan BMD, barang milik daerah yang sedang dalam status dioperasikan oleh pihak lain, dan/atau BMD yang sedang menjadi objek pemanfaatan.

\section{Penghapusan}

Prosedur penghapusan dapat digunakan untuk penghapusan aset dan penghapusan sebagian aset. Penghapusan aset menunjuk aset yang akan dihapuskan dari register aset. Prosedur ini dapat dilakukan apabila telah terbit Surat Keputusan Penghapusan BMD oleh Pengelola Barang Daerah.

Pihak yang berwenang menetapkan keputusan penghapusan BMD adalah pengelola barang, pengguna barang dan pejabat eselon I pengelola BMD. Meski pengelola barang dan pengguna barang sama-sama berwenang menetapkan keputusan penghapusan BMD, namun penghapusan oleh pengguna barang harus memperoleh persetujuan pengelola barang terlebih dahulu.

\subsection{Barang Milik Daerah}

Peraturan Pemerintah Republik Indonesia Nomor 27 Tahun 2014 pasal 1 menjelaskan

1. Barang Milik Negara adalah semua barang yang dibeli atau diperoleh atas beban Anggaran Pendapatan dan Belanja Negara atau berasal dari perolehan lainnya yang sah.

2. Barang Milik Daerah adalah semua barang yang dibeli atau diperoleh atas beban Anggaran Pendapatan dan Belanja Daerah atau berasal dari perolehan lainnya yang sah.

Peraturan Menteri Dalam Negeri Nomor 27 Tahun 2014 Pasal 2 menyatakan bahwa:

(1) Barang Milik Negara/Daerah meliputi:

a. Barang yang dibeli atau diperoleh atas beban Anggaran Pendapatan dan Belanja Negara/Daerah; dan

b. Barang yang berasal dari perolehan lainnya yang sah. meliputi:

1. Barang yang diperoleh dari hibah/sumbangan atau yang sejenis;

2. Barang yang diperoleh sebagai pelaksanaan dari perjanjian/kontrak;

3. Barang yang diperoleh sesuai dengan ketentuan peraturan perundang-undangan; atau

4. Barang yang diperoleh berdasarkan putusan pengadilan yang telah berkekuatan hukum tetap.

Menurut M. Yusuf (2010:13) Barang Milik Daerah merupakan salah satu unsur penting dalam rangka penyelenggaraan pemerintah dan pelayanan kepada masyarakat, oleh karena itu harus dikelola dengan baik dan benar sehingga akan terwujud ppengelolaan barang daerah yang transparan, efisien, akuntabel dan adanya kepastian nilai yang dapat berfungsi sesuai dengan tugas pokok dan fungsi dari pemerintah daerah.

\section{METODE PENELITIAN}

\subsection{Jenis Penelitian}

Penelitian ini merupakan penelitian yang bersifat Deksriptif. Metode penelitian deksriptif dalam kajian dalam kajian metodologi penelitian ini selalu dikaitkan dengan persoalan tujuan penelitian. 


\subsection{Tempat dan Waktu Penelitian}

Lokasi penelitian yang diteliti penulis bertempat di Badan Pengelola Keuangan dan Aset Daerah Kota Manado. Waktu Penelitian dilaksanakan pada bulan Maret 2017-Selesai.

\subsection{Prosedur Penelitian}

Prosedur yang dilakukan dalam penelitian ini adalah :

1. Menentukan judul dan merumuskan masalah;

2. Pengumpulan data melalui wawancara terhadap pihak-pihak yang terkait serta pengambilan data-data di Badan Pengelola Keuangan dan Aset Daerah Kota Manado;

3. Mengelola data dan menginterprestasikan hasil pengelola data;

4. Menarik kesimpulan dan memberikan saran yang dianggap perlu sebagai perbaikan dalam masalah yang ada;

5. Mengumpulkan data sesuai permasalahan yang diangkat.

\subsection{Jenis dan Sumber Data}

\subsubsection{Jenis Data}

Jenis data yang digunakan pada peneliitian ini adalah :

1. Data kualitatif merupakan data yang disajikan secara deskriptif atau data yang berbentuk uraian.

2. Data kuantitatif merupakan data yang disajikan dalam bentuk numerik atau angka-angka. Jenis data yang digunakan dalam penelitian ini adalah data kualitatif mengenai Penerapan Sistem Informasi Manajemen Daerah Barang Milik Daerah pada Badan Pengelola Keuangan dan Aset Daerah Kota Manado.

\subsubsection{Sumber Data}

Data yang dikumpulkan dalam penelitian ini adalah data sekunder dan data primer.

1. Data Primer (Primary Data)

Data yang diperoleh langsung dari perusahaan seperti : sejarah perusahaan struktur organisasi dan informasi lain yang berkaitan dengan penelitian

2. Data Sekunder (Secondary Data)

Data yang diperoleh dari makalah ilmiah dan data kepustakaan

Sumber data yang digunakan penulis dalam penulisan skripsi ini adalah data primer adalah data yang diambil langsung dari Badan Pengelola Keuangan dan Aset Daerah Kota Manado.

\subsection{Teknik Pengumpulan Data}

Metode yang digunakan dalam pengumpulan data-data untuk penelitian ini adalah :

1. Metode Observasi

Metode Observasi merupakan pengumpulan data yang dilakukan dengan cara mengamati dan terjun langsung ke objek yang diteliti dan dari penelitian ini sebagian besar berasal dari sub bagian pembukaan sebagai pihak yang benar-benar melakukan fungsi akuntansi dan bagian aset/BMD.

2. Metode Wawancara

Metode Wawancara dilakukan langsung terhadap pimpinan, pelaksana atau pegawai pada Badan Pengelola Keuangan dan Aset Daerah Kota Manado.

\section{Metode Dokumentasi}

Metode Dokumentasi yaitu pengumpulan data dengan cara mempelajari dokumen, buktibukti atau catatan, arsip yang bersifat tulisan. Pengumpulan data dokumentasi menggunakan alat tulis manual maupun elektronik.

\subsection{Teknik Analisis Data}

Metode yang digunakan adalah metode analisis deskriptif, yaitu suatu metode pembahasan masalah yang sifatnya menguraikan, menggambarkan, membandingkan suatu data atau keadaan serta melukiskan dan menerangkan suatu keadaan sedemikian rupa sehingga dapatlah ditarik suatu kesimpulan. 


\section{HASIL PENELITIAN DAN PEMBAHASAN}

\subsection{Hasil Penelitian}

Program Aplikasi Komputer SIMDA-BMD ini pada dasarnya digunakan untuk melakukan proses pengelolaan Barang Milik Daerah (BMD) secara otomatis dengan memanfaatkan pengolahan data elektronik. Menu-menu yang terdapat dalam Aplikasi Pengolahan BMD digunakan untuk mencatat dan mengadministrasikan mutasi barang daerah atau aset tetap daerah sesuai ketentuan. Diharapkan program aplikasi ini akan dapat memenuhi kebutuhan Pemerintah Daerah, baik di Satuan Kerja Pengelola Keuangan Daerah maupun Satuan Kerja Perangkat Daerah Daerah, yang dalam hal ini selalu berhubungan dengan administrasi semua jenis aset dan barang milik daerah.

Dalam penatausahaan aset daerah, pengurus barang merupakan personil yang bertugas mengoperasikan aplikasi SIMDA-BMD. Dalam melakukan pemrosesan data BMD, pengurus barang dapat memanfaatkan menu Data Entry di aplikasi SIMDA-BMD.

1. Perencanaan

Prosedur perencanaan merupakan tahap awal dalam siklus pengelolaan BMD. Di dalam aplikasi SIMDA-BMD prosedur perencanaan mencakup Rencana

Pengadaan dan Rencana Pemeliharaan. Perencanaan adalah rangkaian kegiatan dalam memenuhi kebutuhan dengan memperhatikan kemampuan keuangan daerah, dan secara terinci memuat nama barang, banyaknya barang, waktu dan biaya.

\section{Pengadaan}

Prosedur pengadaan pada aplikasi SIMDA-BMD merupakan prosedur lanjutan dari prosedur perencanaan yang mencakup Data Pengadaan (untuk aset baru) dan Inventarisasi/sensus (untuk aset yang sudah ada). Pada bagian Data Pengadaan dapat digunakan untuk memantau proses pengadaan BMD sebelum dicatat sebagai aset.

3. Penggunaan

Prosedur penggunaan dapat dimanfaatkan untuk mencatat data pengguna/pemakai BMD berdasarkan Surat Keputusan Penggunaan BMD yang telah ditetapkan. Penetapan status penggunaan barang milik daerah berupa tanah dan bangunan dilakukan apabila diperlukan untuk kepentingan penyelenggaraan tugas dan fungsi pengguna barang atau kuasa pengguna barang yang bersangkutan.

4. Penatausahaan

Pengguna/Kuasa pengguna wajib mencatat BMD pada Daftar Barang Pengguna (DBP)/(DBKP) yang disediakan secara teratur dan menyimpan bukti kepemilikkannya. Prosedur penatausahaan dalam BPKAD merupakan prosedur yang digunakan untuk mengelola BMD dalam kegiatan mengubah data, memindah/mutasi BMD, kapitalisasi, koreksi dan mengubah kondisi BMD.

\section{Pemanfaatan}

Prosedur pemanfaatan digunakan untuk mengelompokan BMD berdasarkan pemanfaatannya. Dalam aplikasi SIMDA-BMD jenis-jenis pemanfaatan meliputi: fasilitas sosial, fasilitas umum, sewa guna usaha, kerja sama operasi, bangun serah guna dan bangun guna serah. Pemanfaatan barang milik daerah dapat dilakukan sepanjang tidak mengganggu pelaksanaan tugas dan fungsi penyelenggaraan pemerintahan daerah.

6. Pemeliharaan

Prosedur ini dimaksudkan untuk mengolah data transaksi pemeliharaan BMD yang akan tercatat dalam riwayat namun tidak menambah kapitalisasi aset.

Rencana Kebutuhan Barang Milik Daerah (RKBMD) pemeliharaan barang milik daerah tidak dapat diusulkan oleh pengguna barang dan/atau kuasa pengguna barang terhadap barang milik daerah yang berada dalam kondisi rusak berat, barang milik daerah yang sedang dalam status penggunaan sementara. RKBMD pemeliharaan BMD diusulkan oleh pengguna barang 
yang sementara menggunakan BMD, barang milik daerah yang sedang dalam status dioperasikan oleh pihak lain, dan/atau BMD yang sedang menjadi objek pemanfaatan.

7. Penghapusan

Prosedur penghapusan dapat digunakan untuk penghapusan aset dan penghapusan sebagian aset. Penghapusan aset menunjuk aset yang akan dihapuskan dari register aset. Prosedur ini dapat dilakukan apabila telah terbit Surat Keputusan Penghapusan BMD oleh Pengelola Barang Daerah.

\subsection{Pembahasan}

Penerapan SIMDA-BMD

Salah satu aplikasi dalam mengelola keuangan daerah yang telah dikembangkan adalah program aplikasi komputer Sistem Informasi Manajemen Daerah Barang Milik Daerah (SIMDA-BMD) yang dapat digunakan sebagai pengolah data pengelolaan barang dan aset pemerintah daerah. Dengan adanya program aplikasi ini diharapkan dapat memudahkan SKPD untuk menyajikan laporan, karena sebelumnya secara offline atau manual itu sangat memakan waktu.

Berdasarkan Pedoman Pengoperasian Aplikasi Sisrem Informasi Manajemen Daerah Barang Milik Daerah yang digunakan Badan Pengelola Keuangan dan Aset Daerah Kota Manado sebagai acuan, jenis kegiatan dan hal-hal yang harus dilakukan SKPD serta yang telah dilakukan SKPD adalah sebagai berikut :

\begin{tabular}{|c|c|c|c|c|}
\hline No. & Kegiatan & $\begin{array}{c}\text { Yang harus } \\
\text { dilaksanakan } \\
\text { SKPD }\end{array}$ & $\begin{array}{c}\text { Yang } \\
\text { dilaksanakan } \\
\text { SKPD }\end{array}$ & Output \\
\hline 1. & Perencanaan & $\begin{array}{l}\text { - Mengisi data-data } \\
\text { kode barang serta } \\
\text { keterangannya. } \\
\\
\text { - Untuk rencana } \\
\text { pemeliharaan, klik } \\
\text { menu rencana } \\
\text { pemeliharaan dan } \\
\text { isi data-data barang } \\
\text { dan penjelasannya, }\end{array}$ & $\begin{array}{l}\text { - Badan Pengelola } \\
\text { Keuangan dan Aset } \\
\text { Daerah Kota } \\
\text { Manado sudah } \\
\text { mengisi data-data } \\
\text { kode barang serta } \\
\text { keterangannya. } \\
\\
\text { - Badan Pengelola } \\
\text { Keuangan dan Aset } \\
\text { Daerah sudah } \\
\text { mengisi data-data } \\
\text { dan penjelasan } \\
\text { barang untuk } \\
\text { rencana } \\
\text { pemeliharaan. }\end{array}$ & $\begin{array}{l}\text {-Daftar } \\
\text { Kebutuhan Barang } \\
\text { dan Pemeliharaan; } \\
\text {-Daftar Rencana } \\
\text { Pengadaan Barang } \\
\text { Daerah; } \\
\text {-Daftar Rencana } \\
\text { Pemeliharaan } \\
\text { Barang Daerah } \\
\text { yang dapat } \\
\text { dijadikan dasar } \\
\text { dalam } \\
\text { pelaksanaan } \\
\text { pengadaan BMD. }\end{array}$ \\
\hline 2. & $\begin{array}{l}\text { Pengadaan } \\
\text { (untuk data } \\
\text { pengadaan) }\end{array}$ & $\begin{array}{l}\text { - Mengisi data } \\
\text { Kontrak/Surat } \\
\text { Perintah Kerja }\end{array}$ & $\begin{array}{l}\text { - Badan Pengelola } \\
\text { Keuangan dan Aset } \\
\text { Daerah Kota } \\
\text { Manado sudah } \\
\text { mengisi data } \\
\text { Kontrak/Surat } \\
\text { Perintah Kerja. }\end{array}$ & $\begin{array}{l}\text { - Daftar Hasil } \\
\text { Pengadaan; } \\
\text { - Daftar Hasil } \\
\text { Pemeliharan } \\
\text { Barang; } \\
\text { - Daftar Kontrak } \\
\text { Pengadaan }\end{array}$ \\
\hline
\end{tabular}




\begin{tabular}{|c|c|c|c|c|}
\hline No. & Kegiatan & $\begin{array}{c}\text { Yang harus } \\
\text { dilaksanakan } \\
\text { SKPD } \\
\end{array}$ & $\begin{array}{c}\text { Yang } \\
\text { dilaksanakan } \\
\text { SKPD } \\
\end{array}$ & Output \\
\hline & $\begin{array}{l}\text { (untuk } \\
\text { inventarisasi) }\end{array}$ & $\begin{array}{l}\text { - Mengisi rincian } \\
\text { pengadaan barang } \\
\text { - Mengisi SP2D } \\
\text { pencairan, dan } \\
\text { mengisi belanja } \\
\text { penunjang, } \\
\\
\text { - Melakukan } \\
\text { posting data aset ke } \\
\text { dalam KIB. } \\
\\
\text { - Menginput hasil } \\
\text { inventarisasi fisik } \\
\text { seperti : Tanah, } \\
\text { peralatan dan } \\
\text { mesin, } \\
\text { gedung dan } \\
\text { bangunan, jalan } \\
\text { Irigasi dan } \\
\text { jaringan, } \\
\text { aset tetap lainnya, } \\
\text { dan konstruksi } \\
\text { dalam pekerjaan. }\end{array}$ & $\begin{array}{l}\text { - BPKAD sudah } \\
\text { mengisi rincian } \\
\text { untuk pengadaan } \\
\text { barang. } \\
\text { - BPKAD sudah } \\
\text { mengisi SP2D } \\
\text { pencairan dan } \\
\text { belanja penunjang. } \\
\text { - BPKAD sudah } \\
\text { melakukan posting } \\
\text { data aset ke dalam } \\
\text { KIB. } \\
\text { - BPKAD sudah } \\
\text { menginput hasil } \\
\text { inventarisasi fisik, } \\
\text { berdasarkan aset } \\
\text { yang sudah } \\
\text { dilaksanakan. }\end{array}$ & \\
\hline 3. & Penggunaan & $\begin{array}{l}\text { - Menginput } \\
\text { surat keputusan } \\
\text { penggunaan aset } \\
\text { tetap yang } \\
\text { ditetapkan oleh } \\
\text { Kepala Daerah. }\end{array}$ & $\begin{array}{l}\text {-BPKAD sudah } \\
\text { melakukan } \\
\text { penginputan dalam } \\
\text { SIMDA untuk surat } \\
\text { keputusan } \\
\text { penggunaan aset. }\end{array}$ & $\begin{array}{l}\text {-Data } \\
\text { pengguna/pemakai } \\
\text { BMD }\end{array}$ \\
\hline 4. & Penatausahaan & $\begin{array}{l}\text { - Pengguna atau } \\
\text { Kuasa pengguna } \\
\text { wajib mencatat } \\
\text { BMD pada Daftar } \\
\text { Barang Pengguna } \\
\text { (DBP)/(DBKP) } \\
\text { yang disediakan } \\
\text { secara teratur. } \\
\text { - Lanjut untuk }\end{array}$ & $\begin{array}{l}\text { - Pengguna atau } \\
\text { Kuasa pengguna } \\
\text { pada BPKAD } \\
\text { sudah mencatat } \\
\text { BMD pada Daftar } \\
\text { Barang Pengguna } \\
\text { (DBP/(DBKP). } \\
\text { - BPKAD sudah }\end{array}$ & $\begin{array}{l}\text { - Kartu Inventaris } \\
\text { Barang (KIB); } \\
\text { - Kartu (sejarah) } \\
\text { Barang; } \\
\text { - Kartu Inventaris } \\
\text { Ruangan (KIR); } \\
\text { - Buku Inventaris } \\
\text { (BI); }\end{array}$ \\
\hline
\end{tabular}




\begin{tabular}{|c|c|c|c|c|}
\hline No. & Kegiatan & $\begin{array}{l}\text { Yang harus } \\
\text { dilaksanakan } \\
\text { SKPD }\end{array}$ & $\begin{array}{c}\text { Yang } \\
\text { dilaksanakan } \\
\text { SKPD }\end{array}$ & Output \\
\hline & & $\begin{array}{l}\text { mengubah data } \\
\text { KIB, isi data } \\
\text { sebagai berikut : } \\
\text { • No. dan tanggal } \\
\text { dokumen } \\
\text { perubahan, } \\
\text { keterangan } \\
\text { - Data dokumen } \\
\text { yang terkait } \\
\text { masing-masing } \\
\text { jenis aset. } \\
\text { - Untuk pindah } \\
\text { SKPD, memilih } \\
\text { aset yang akan } \\
\text { dilakukan } \\
\text { penginputan } \\
\text { kemudian pilih } \\
\text { SKPD tujuan. } \\
\\
\text { - Lanjut untuk } \\
\text { kapitalisasi, isi data } \\
\text { kapitalisasi untuk } \\
\text { aset yang } \\
\text { bersangkutan. }\end{array}$ & $\begin{array}{l}\text { mengisi data-data } \\
\text { perubahan data } \\
\text { pada KIB sesuai } \\
\text { dengan ketentuan. } \\
\\
\text { - BPKAD sudah } \\
\text { melakukan seperti } \\
\text { yang diharuskan. } \\
\\
\text { - BPKAD sudah } \\
\text { mengisi data } \\
\text { kapitalisasi untuk } \\
\text { aset yang } \\
\text { bersangkutan. }\end{array}$ & $\begin{array}{l}\text { - Daftar Mutasi } \\
\text { Barang Daerah, } \\
\text { dan Rekap Hasil } \\
\text { Sensus; } \\
\text { - Label Barang. }\end{array}$ \\
\hline 5. & Pemanfaatan & $\begin{array}{l}\text { - Menginput data } \\
\text { dalam SIMDA } \\
\text { mengenai } \\
\text { pemanfaatan } \\
\text { seperti nomor } \\
\text { dokumen dsb. }\end{array}$ & $\begin{array}{l}\text { - BPKAD sudah } \\
\text { melakukan } \\
\text { penginputan data } \\
\text { dalam SIMDA } \\
\text { untuk pemanfaatan } \\
\text { dengan mengisi } \\
\text { data yang diminta. }\end{array}$ & \\
\hline 6. & Pemeliharaan & $\begin{array}{l}\text { - Mengisi data } \\
\text { untuk pemeliharaan } \\
\text { seperti: No. SP2D, } \\
\text { tgl SP2D, no. } \\
\text { kontrak, sampai } \\
\text { pada keterangan. }\end{array}$ & $\begin{array}{l}\text { - BPKAD sudah } \\
\text { melakukan } \\
\text { pengisian data } \\
\text { untuk pemeliharaan } \\
\text { dengan mengisi } \\
\text { data-data seperti } \\
\text { yang diminta. }\end{array}$ & \\
\hline 7. & $\begin{array}{l}\text { Penghapusan } \\
\text { (untuk } \\
\text { penghapusan } \\
\text { sebagian aset) }\end{array}$ & $\begin{array}{l}\text { - Menginput data } \\
\text { penghapusan } \\
\text { sebagian aset } \\
\text { dengan memilih } \\
\text { salah satu jenis aset } \\
\text { dan tidak akan } \\
\text { menghapus } \\
\text { rekening aset. }\end{array}$ & $\begin{array}{l}\text { - BPKAD sudah } \\
\text { melakukan } \\
\text { penginputan data } \\
\text { untuk penghapusan } \\
\text { sebgaian aset. }\end{array}$ & $\begin{array}{l}\text { - Surat Keputusan } \\
\text { Penghapusan; } \\
\\
\text { - Lampiran Surat } \\
\text { Keputusan } \\
\text { Penghapusan; } \\
\text { - Daftar Barang }\end{array}$ \\
\hline
\end{tabular}




\begin{tabular}{|c|c|c|c|c|}
\hline No. & Kegiatan & $\begin{array}{c}\text { Yang harus } \\
\text { dilaksanakan } \\
\text { SKPD }\end{array}$ & $\begin{array}{c}\text { Yang } \\
\text { dilaksanakan } \\
\text { SKPD }\end{array}$ & Output \\
\hline & $\begin{array}{l}\text { (untuk } \\
\text { penghapusan } \\
\text { aset) }\end{array}$ & $\begin{array}{l}\text { - Mengisi data } \\
\text { penghapusan } \\
\text { nomor SK, tanggal } \\
\text { SK dan keterangan } \\
\text { kemudian } \\
\text { menginput rincian } \\
\text { penghapusan, isi } \\
\text { data UPB, kode } \\
\text { barang, nilai, } \\
\text { alasan dan } \\
\text { keterangan. }\end{array}$ & $\begin{array}{l}\text { - BPKAD sudah } \\
\text { melakukan } \\
\text { pengisian data serta } \\
\text { menginput rincian } \\
\text { penghapusan aset. }\end{array}$ & yang Dihapuskan \\
\hline
\end{tabular}

Dengan melihat kegiatan-kegiatan tersebut maka Penerapan Sistem Informasi Manajemen Daerah pada Badan Pengelola Keuangan dan Aset Daerah Kota Manado sangat membantu Pemerintah Daerah dalam mengelola barang milik daerah, dan juga SIMDA memberikan kelengkapan penjelasan yang terlihat dalam output yang dihasilkan serta cepat dalam menghasilkan laporan. Ada juga kekurangan SIMDA yaitu aplikasi SIMDA belum kompatibel apabila dibuka dalam Windows 10, jadi pada windows 10 SIMDA harus dibuka secara online. Dalam BPKAD sendiri juga menggunakan aplikasi SIMDA ver. 2.0.

\section{KESIMPULAN DAN SARAN}

\section{Kesimpulan}

Berdasarkan hasil penelitian maka dapat dibuat kesimpulan sebagai berikut:

1 Aplikasi SIMDA-BMD yang diterapkan pada Badan Pengelola Keuangan dan Aset Daerah Kota Manado sebagai aplikasi berbasis computer sangat membantu pemerintah mengelola barang milik daerah sehingga dapat menghasilkan laporanlaporan yang berguna bagi pemerintah daerah yang dapat digunakan untuk pengambilan keputusan untuk rencana yang akan datang.

2. Dalam penatausahaan aset daerah, khususnya mengoperasikan aplikasi SIMDA-BMD yang memanfaatkan 7 menu Data Entry yaitu : Perencanaan, Pengadaan, Penggunaan, Penatausahaan, Pemanfaatan, Pemeliharaan, Penghapusan sudah sangat lengkap dan lancar di operasikan pada Badan Pengelola Keuangan dan Aset Daerah Kota Manado.

3. Informasi-informasi yang dihasilkan SIMDA-BMD pada Badan Pengelola Keuangan dan Aset Daerah Kota Manado sangat penting dan sangat membantu Pemerintah Daerah dalam menjalankan tugasnya.

4. Aplikasi SIMDA pada BPKAD Kota Manado sangat baik dalam hal jenis laporan yang dihasilkan dan kecepatan dalam menghasilkan laporan yang akan digunakan SKPD.

\section{Saran}

Adapun saran yang dapat diberikan adalah :

1. Bagi Badan Pengelola Keuangan dan Aset Daerah Kota Manado agar lebih menjaga kualitas dan tetap mengikuti perkembangan aplikasi SIMDA-BMD karena itu sangat berguna dan sangat membantu pemerintah dalam pengelolaan aset daerah. 
2. Pihak Badan Pengelola Keuangan dan Aset Daerah Kota Manado dalam mengoperasikan aplikasi SIMDA-BMD yang memanfaatkan 7 menu Data Entry yaitu Perencanaan, Pengadaan, Penggunaan, Penatausahaan, Pemanfaatan, Pemeliharaan, Penghapusan agar sering di adakan pelatihan/diklat bagi pegawai yang memegang tanggung jawab tersebut.

3. Sebaiknya Badan Pengelola Keuangan dan Aset Daerah Kota Manado untuk lebih meningkatkan lagi pelatihan/diklat untuk menambah wawasan, kreativitas dan kinerja pegawai sehingga tujuan instansi akan mudah untuk dicapai.

4. Pihak Badan Pengelola Keuangan dan Aset Daerah Kota Manado harus mengupdate SIMDA, sehingga dapat menghasilkan output yang dibutuhkan dengan SIMDA ver. terakhir.

\section{DAFTAR PUSTAKA}

Badan Pengawasan Keuangan dan Pembangunan, Peraturan Pemerintah Nomor 60 Tahun 2008 Tentang Sistem Pengendalian Internal Pemerintah.(www.bpkp.go.id).

Gelinas dan Dull 2012, Accounting information system 9th Edition. South Western Cengage Learning.

Halim, Abdul. 2013. Akuntansi Keuangan Daerah. Edisi Keempat. Salemba Empat. Jakarta.

Halim, Abdul dan Muhammad S. Kusufi. 2012. Akuntansi Sektor Publik Akuntansi Keuangan Daerah. Edisi Empat. Erlangga, Jakarta. Hariadi. P., Restianto, dan Bawono. 2015. Pengelola Keuangan Daerah. Salemba Empat, Jakarta.

Hari Laksono (2015). Evaluasi kesuksesan Sistem Informasi Manajemen Daerah Barang Milik Daerah pada pemerintah kabupaten Klaten. Etd.repository.ugm.ac.id

Mardiasmo, 2012. "Akuntansi Sektor Publik" Penerbit Andi. Yogyakarta

Mursyidi 2012 “akuntansi pemerintah di Indonesia”. Bandung: Penerbit Refika Aditama.

Peraturan Pemerintah Nomor 71 Tahun 2010 Tentang Standar Akuntansi Pemerintahan (www.kemenkeu.go.id).

Peraturan Menteri Keuangan Republik Indonesia Nomor 171/PMK. 05/2011 Tentang Sistem Akuntansi dan Pelaporan Keuangan Pemerintah Pusat. Jakarta: Kementerian Keuangan. Peraturan Pemerintah No. 14 tahun 2014, Pengelolaan Barang Milik Daerah

Pontoh, Winston. 2013 "Akuntansi Konsep dan Aplikasi”. Penerbit Halaman Moeka, Jakarta.

Satgas Pengembangan SIMDA. 2011. Bimbingan Teknis SIMDA keuangan. Manado: Badan Pemeriksa Keuangan dan Pembangunan.

Sadeli, Lili. 2015. Dasar-dasar Akuntansi. Edisi Pertama. Bumi Aksara, Jakarta.

Sujarweni, Wiratna. 2015. Akuntansi Sektor Publik. Pustaka Baru Press, Yogyakarta.

Suwardjono. 2013. Teori Akuntansi Perekayasaan Pelaporan Keuangan. Edisi Ketiga, BPFE, Yogyakarta. 